\title{
Molecular Characterization of Cellulolytic Bacteria Derived From Termite Gut and Optimization of Cellulase Production
}

\author{
V.S. Shinde ${ }^{1 *}$, T. Agrawal ${ }^{1}$ and A.S. Kotasthane ${ }^{2}$ \\ ${ }^{1}$ Department of Plant Molecular Biology and Biotechnology, IGKV, Raipur-492012, India \\ ${ }^{2}$ Department of Plant Pathology, IGKV, Raipur-492012, India \\ *Corresponding author
}

\section{A B S T R A C T}

\begin{tabular}{|l|}
\hline Ke y w o r d s \\
Cellulase, DNS, \\
Optimization, 16s \\
rRNA \\
identification, \\
ERIC-REP-BOX. \\
\hline Article Info \\
\hline $\begin{array}{l}\text { Accepted: } \\
\text { 21 September } 2017 \\
\text { Available Online: } \\
\text { 10 October } 2017\end{array}$ \\
\hline
\end{tabular}

Keywords

Cellulase, DNS, Optimization, 16s RNA

identification, ERIC-REP-BOX.

\section{Introduction}

Lignocellulose, the major component of plant cell walls, is the most abundant and sustainable biomass on the earth, and is recognized for its potential for renewable energy production (Arakawa 2008, Scharf 2009). It is a general term which refers to a structure made up of three dominant compounds cellulose, hemicellulose and lignin. For the degradation of lignocellulose, diversity of enzymes is required which can be classified as, endo- $\beta$ - 1 , 4-glucanase (CMCase or endoglucanase), exo- $\beta-1, \quad 4$-glucanase (exocellulase, avicelase) and $\beta$-glucosidase (cellobiase). All of the three enzymes are involved in breaking the complex polymer into fermentable sugars. Endo- $\beta$ - 1 , 4glucanases are needed to break glucosidic bonds for creating free chain ends whereas, exoglucanase are required for the degradation of the same molecule by removing cellobiose units remaining at the free chain ends and $\beta$ glucosidase which hydrolyzes cellobiose into simple sugars. Insects have evolved very effective strategies to use lignocellulosic substrates as a source of energy (Willis et al., 2010). This makes them an optimal source for prospect of novel cellulolytic enzymes. Termites are one of the most lignocellulose digesting insects and can act as one of the best source for cellulolytic systems as microbial 
communities inside the gut are known to produce cellulase. Under optimal conditions, cellulase can convert complex polymers (cellulose) in to simple sugars (glucose).Cellulose has attracted worldwide attention as a renewable resource that can be converted into bio based products and energy (Li et al., 2009). One of the limiting steps in the biomass-to-ethanol process is the degradation of cellulose to fermentable sugars (saccharification). This currently relies on the use of bacterial and/or fungal cellulases, which tend to have low activity under biorefinery conditions and are easily inhibited (Fischer et al., 2013).Application of these enzymes can serve as source for lignocellulose degradation not only in industries but also at field level for decomposing lignocellulosic biomass which remains in the field after harvesting. Keeping these facts in mind, we carried out optimization of the the parameters for cellulase production and identification of these microbes at molecular level.

\section{Materials and Methods}

The bacteria used in this study were previously isolated from the gut of termites which were collected from different geographical locations of Chhattisgarh, India (Shinde et al., 2017). Out of 33 isolates, 16 isolates (B1, B2, B3, C1, C2, C3, M1, A1, Z1, $\mathrm{L}, \mathrm{R}, \mathrm{N}, \mathrm{Z}, \mathrm{B} 1$ plate, $\mathrm{B}$ and $\mathrm{C}$ ) were found potential cellulase producers by forming halo zoneson the media supplemented with CMC as a sole carbon source. The pure colonies of the isolates were maintained in NAM slants at $16^{\circ} \mathrm{C}$ for further studies.

\section{Preparation of crude enzyme}

Bacterial isolates were inoculated in conical flasks containing sterilized nutrient broth $(25$ $\mathrm{ml}$ ) and incubated at $37^{\circ} \mathrm{C}$ for 48 hours. After 48 hours, bacterial cultures were centrifuged at $8000 \mathrm{rpm}$ for 10 minutes. After centrifugation, supernatant was collected as a source of crude enzyme and stored at $4{ }^{\circ} \mathrm{C}$ for enzyme assays.

\section{Cellulase activity assay}

Enzyme activity of crude cellulase was estimated with the help of different commercially available chemical substrates, such as carboxymethyl cellulose (CMC) avicel and filter paper. The amount of the reducing sugars released was determined according to the DNS method (Miller et al., 1959) with some modifications. The amount of reducing sugar was calculated from a previous established standard curve using Dglucose as a standard. Carboxymethylcellulase (CMCase) activity was expressed in terms of units. One unit is the amount of enzyme releasing $1 \mu \mathrm{mol}$ of reducing sugar from carboxymethyl celluloseper $\mathrm{ml}$ per min. One unit of Avicelase activity was defined as the amount of enzyme released $1 \mu \mathrm{mol}$ of reducing sugars from avicel per $\mathrm{ml}$ per min. Filterpaperase (FPase) activity was determined by using a method described by wood and Bhat (1988) with some modifications. One unit is the amount of enzyme in the culture filtrate releasing $1 \mu \mathrm{mol}$ of reducing sugars from filter paper per min. Filter paperase (FPase) is expressed in terms of filter paper units (FPU).

\section{Optimization of different parameters for determining maximum cellulase activity}

Different parameters like $\mathrm{pH}$, temperature, and incubation period were optimized for carboxymethylcellulase (CMCase), avicelase (exoglucanase) and filterpaperase (FPase) production. For the optimization of temperature, experiment was carried out at different temperatures $\left(30^{\circ} \mathrm{C}, 35^{\circ} \mathrm{C}, 40^{\circ} \mathrm{C}\right.$, $45^{\circ} \mathrm{C} \& 50^{\circ} \mathrm{C}$ ). To study the effect of $\mathrm{pH}$ on cellulase enzyme activity, different buffers 
such as $50 \mathrm{mM}$ sodium citrate $(\mathrm{pH} 5-6)$, $50 \mathrm{mM}$ potassium phosphate $(\mathrm{pH} 7)$, $50 \mathrm{mMTrisHcl}(\mathrm{pH} 8)$ were prepared. To 0.5 $\mathrm{ml}$ of crude enzyme, $0.5 \mathrm{ml}$ of $1 \% \mathrm{CMC}, 0.5$ $\mathrm{ml}$ of $1 \%$ avicel, Whatman filter paper strip (1 $\mathrm{x} 6 \mathrm{~cm}$ ) in the above buffers was added. To determine optimum incubation period, bacterial cultures growing in nutrient broth were taken out at the different time intervals and the enzyme activity was determined.

\section{DNA extraction}

For the DNA extraction, bacterial isolates were inoculated in nutrient broth and incubated for $48 \mathrm{hrs}$. DNA was isolated by using Ultraclean ${ }^{\circledR}$ Microbial DNA isolation kit, $M O-B I O$ Laboratories.

\section{Identification of bacterial isolates on the basis of 16s rRNA gene amplification}

The 16s rRNA gene was amplified by using a set of universal primers according to Khianngam et al., 2014: 27F (5'AGAGTTTGATCCTGGCTCAG3') and 1492R (5'GGTTACCTTGTTACGACTT3'). PCR was carried out in $10 \mu \mathrm{l}$ reaction mixture containing $1 \mathrm{X}$ assay buffer $(1 \mathrm{mM})$ Tris- $\mathrm{HCl}$ at $\mathrm{pH} 9.0,50 \mathrm{mM} \mathrm{KCl}, 2.5 \mathrm{mM} \mathrm{MgCl} 2$, $0.1 \mathrm{mM}$ each dNTP mix, $1 \mu \mathrm{M}$ both forward and reverse primers, 50-60ng of template DNA and $0.4 \mathrm{U}$ Taq DNA polymerase (Axygen) in BIORAD $\mathrm{T}^{100^{\mathrm{TM}}}$ Thermocycler according to following temperature profiles: $95^{\circ} \mathrm{C}$ for $5 \mathrm{~min}, 30$ cycles of 30 seconds at $95^{\circ} \mathrm{C}, 55^{\circ} \mathrm{C}$ for $1 \mathrm{~min}, 72^{\circ} \mathrm{C}$ for $1 \mathrm{~min}$ and final elongation at $72^{\circ} \mathrm{C}$ for $7 \mathrm{~min}$.

\section{ERIC-BOX-REP PCR based genotypic analysis}

ERIC, REP, BOX primer sequences were used in PCR to detect differences in the number and distribution of these bacterial repetitive sequences in the bacterial genome.
Primers sequences and temperature profiles used in the study are shown in Table 1and Table 2 .

\section{Bioinformatics analysis and phylogenetic} tree construction

The purified products were sent for sequencing to DNA sequencing facility. The data obtained after sequencing was compared with the online data base at GenBank using BLAST-N search program in NCBI. (http://www.ncbi.nlm.nih.gov). The sequences were aligned and phylogenetic tree was constructed using software MEGA 6.0 with neighbor-joining method at $1000 \mathrm{x}$ bootstraps (Tamura et al., 2011).

\section{Statistical analysis}

All the experiments were arranged in completely randomized block design with two replications in each treatment. Specific PCR amplification products (ERIC, BOX and REP) were scored as present (1) or absent (0) depending on decreasing order of their molecular weights of DNA sample. The presence or absence of bands was converted into binary data ( 1 for presence and 0 for absence of each band) and similarity matrices were calculated using NTSYS (Numerical Taxonomy System Biostatistics) computer program on binary data of selected groups of primers detailed. Cluster analysis was done within SAHN program by using UPGMA (unweighted pair-group method with arithmetic averages).

\section{Effects of temperature and $\mathrm{pH}$ on growth of bacteria}

To study the effect of $\mathrm{pH}$ on the growth of bacteria, isolates were inoculated in the test tubes containing nutrient broth $\mathrm{pH} 6, \mathrm{pH} 7$, $\mathrm{pH} 8$ ) and kept for two days. To study the effect of temperature on the growth of 
bacteria, isolates were inoculated in the test tubes containing nutrient broth and the tubes were kept at various temperatures, $30^{\circ} \mathrm{C}$, $35^{\circ} \mathrm{C}, 40^{\circ} \mathrm{C}$ and $45^{\circ} \mathrm{C}$. The growth of bacteria was determined spectrophotometrically by taking the O.D at $600 \mathrm{~nm}$.

\section{Results and Discussion}

\section{Effect of temperature, $\mathrm{pH}$ and incubation period on CMCase activity}

All the sixteen potential cellulose degrading bacteria were studied for optimization of parameters for optimum CMCase production. The enzyme activity of potential isolates at different parameters is shown in Table 3. Bacterial isolate $\mathrm{C} 3$ showed maximum CMCase activity at $35^{\circ} \mathrm{C}$ whereas, other isolates $\mathrm{B} 1, \mathrm{~B} 3$ and $\mathrm{C} 1$ showed maximum enzyme activity at $40^{\circ} \mathrm{C}$. Maximum activity for $\mathrm{B} 2$ isolate was found at $45^{\circ} \mathrm{C}$. Other isolates showed efficient activity at $35^{\circ} \mathrm{C}$ (Fig.1). Decrease in the temperature below $35^{\circ} \mathrm{C}$ and increase in the temperature above $45^{\circ} \mathrm{C}$ resulted in low enzyme activity. The data obtained clearly suggests that bacterial cellulase has an optimum temperature between $35^{\circ} \mathrm{C}$ and $45^{\circ} \mathrm{C}$. The data is accordance with the previous studies. Khatiwada et al., 2016 reported maximum CMCase production by Bacillus and pseudomonas species at $37^{\circ} \mathrm{C}$ and Serratia species at $35^{\circ} \mathrm{C}$. Haripriya et al., 2017, Vimal et al., 2016 obtained maximum CMCase activity at $40^{\circ} \mathrm{C}$. Like temperature, $\mathrm{pH}$ is also an important factor that affects the enzyme yield. All the isolates showed maximum CMCase activity at $\mathrm{pH}$ 7. $\mathrm{pH}$ below or above 7 resulted in low enzyme activity (Fig.2). The data obtained clearly indicates that bacterial CMCase has optima $\mathrm{pH} 7$. The results obtained are similar with the previous studies. Sharma et al., 2015 found optimum $\mathrm{pH}$ at 7 for endoglucanase activity by Bacillus sp. isolated from termite. Shaikh et al., 2013 obtained maximum CMCase activity at $\mathrm{pH} 7$ and 7.5 by Pseudomonas and Bacillus sp. Similarly, Effect of incubation time showed variations in cellulase production. The optimum time for cellulase production with CMCase was observed at $48 \mathrm{hrs}$ of incubation period for all the isolates. The cellulase activity was significantly reduced after 48 hours of incubation (Fig.3). The results of the study are in accordance with the previous studies. Vimal et al., 2016 reported maximum cellulase production after 48 hrs by Bacillus sp. Khatiwada et al., 2016 obtained maximum cellulase production after $24 \mathrm{hrs}$ and $48 \mathrm{hrs}$ of incubation time for Bacillus, Serratia and pseudomonas sp. From our study it was found that, maximum CMCase activity was observed at temperature between $35^{\circ} \mathrm{C}$ to $45^{\circ} \mathrm{C}$, at $\mathrm{pH} 7$ and after $48 \mathrm{hrs}$ of incubation period.

\section{Effect of temperature, $\mathrm{pH}$ and incubation period on avicelase activity}

All the sixteen potential cellulose degrading bacteria were studied for optimization of parameters for optimum avicelase production. The enzyme activity of potential isolate at different parameters is shown in Table 4.Avicelase activity was studied between $30^{\circ} \mathrm{C}$ to $45^{\circ} \mathrm{C}$. The data obtained showed that, all isolates have maximum avicelase activity at $35^{\circ} \mathrm{C}$ (Fig.4). Among all isolates, $\mathrm{C} 3$ isolate showed maximum enzyme activity. Avicelase activity was found low at $30^{\circ} \mathrm{C}, 40^{\circ} \mathrm{C}$ and $45^{\circ} \mathrm{C}$ as compared to $35^{\circ} \mathrm{C}$. Increase or decrease in the temperature resulted in low enzyme yield. The results are accordance with the previous studies. A study conducted on isolation, production and optimization of avicelase enzyme from sawdust showed the optimum temperature for avicelase activity was at $37^{\circ} \mathrm{C}$ and $50^{\circ} \mathrm{C}$ (Fauzi et al., 2013). Rani et al., 2015 stated that, the optimum temperature for avicelase activity ranges between $25^{\circ} \mathrm{C}$ to $50^{\circ} \mathrm{C}$ for bacteria, fungi and 
actinomycetes. Likewise, Effect of $\mathrm{pH}$ on avicelase activity indicated that all isolates have maximum enzyme activity at $\mathrm{pH} 7$ (Fig. 5).Among all isolates, isolate $\mathrm{C} 3$ showed highest enzyme activity. Enzyme activity was low after increase and decrease in the $\mathrm{pH}$. The results of the study are similar with the previous studies. A study conducted on isolation, production and optimization of avicelase enzyme from sawdust showed the optimum $\mathrm{pH}$ for avicelase activity was 7 (Fauzi et al., 2013). Rani et al., 2015 stated that, the optimum $\mathrm{pH}$ for avicelase activity ranges between 4.4 to 8 for bacteria, fungi and actinomycetes.

Incubation period for optimum avicelase production was also studied and it was found that, bacterial avicelase has maximum activity after $48 \mathrm{hrs}$ of incubation time (Fig. 6). Enzyme activity was gradually decreased after $48 \mathrm{hrs}$ of incubation time. Rani et al., 2015 stated that, bacterial species like Bacillus subtilis, Geobacillus stearothermophilus has maximum avicelase production after $48 \mathrm{hrs}$ of incubation time. From our study it was found that, maximum avicelase activity was observed at $35^{\circ} \mathrm{C}$ at $\mathrm{pH}$ 7 and after $48 \mathrm{hrs}$ of incubation period.

\section{Effect of temperature, $\mathrm{pH}$ and incubation period on filterpaperase (FPase) activity}

All the sixteen potential cellulose degrading bacteria were studied for optimization of temperature for maximum FPase activity. The enzyme activity of the most potential isolate at different parameters is shown in Table 5. All isolates showed maximum FPase activity at $35^{\circ} \mathrm{C}$. Among all isolates, maximum FPase activity was found at $35^{\circ} \mathrm{C}$ for bacterial isolate $\mathrm{Z}$ as compared to other isolates. FPase activity was decreased after increase in the temperature. Thus, results clearly indicate that bacterial FPase has an optimum temperature at $35^{\circ} \mathrm{C}($ Fig. 7$)$. The results of this study are similar with previously reported studies. Swaroopa Rani et al., 2004 optimized fermentation conditions for filterpaperase and found that activity was maximum at $35^{\circ} \mathrm{C}$. Cultivation at different temperatures and in presence of various carbon sources revealed that all the three strains produced more amounts of endoglucanase, $\beta$-glucosidase and filter-paperase activities at $35^{\circ} \mathrm{C}$ (Sohail et al., 2014). In case of $\mathrm{pH}$, maximum enzyme activity was found at 7 for all isolates. Among all isolates, highest enzyme activity was shown by $\mathrm{Z}$ isolate. FPase activity at $\mathrm{pH} 5$, $\mathrm{pH} 6$ and $\mathrm{pH} 8$ was found low as compared with $\mathrm{pH} 7 . \mathrm{pH}$ below and above 7 resulted in low enzyme activity (Fig. 8). The data obtained clearly showed that, bacterial FPase has optima of $\mathrm{pH}$ 7. Swaroopa Rani et al., 2004 optimized fermentation conditions for filterpaperase and found that activity was maximum at $\mathrm{pH}$ 7. However, optimization and characterization of cellulolytic enzymes produced from Gliocladiumroseum showed FPase has an optimum $\mathrm{pH}$ of 7 (Salem et al., 2015).The effect of incubation period was determined and it showed variations in FPaseproduction. All the isolates showed maximum FPase enzyme production after 48 hrs of incubation period. Highest enzyme activity was shown by $\mathrm{Z}$ isolate as compared to others. Enzyme activity was reduced after 48 hours of incubation period (Fig. 9). The data obtained showed that bacterial FPase has optimum incubation time after $48 \mathrm{hrs}$. The results of the study are found similar with previous studies. Swaroopa Rani et al., 2004 obtained highest FPase activity after $48 \mathrm{hrs}$ on incubation time from Clostridium papyrosolvens CFR-703. Maximum FPase activity was recorded on the 2 nd day of incubation irrespective of carbon sources used, and activity was gradually decreased with the incubation time increases (Yadav et al., 2017).

Molecular identification of potential cellulolytic isolates 
The amplification with 16s rRNA gene primers showed 1300 bpamplicons (Fig. 10). The 16s rRNA gene sequences thus generated were helpful in identifying the isolates at species level. The summary of the 16s rRNA gene sequences are given inTable6. The results 16s rRNA gene analysis in the present study has confirmed that the isolates belong to different strains like, Pseudomonas,
Klebsiella, Salmonella, Serratia and Enterobacter. All the sequences were aligned and phylogenetic tree for the isolate B2 was created using Neighbor-Joining method with the help of software package Mega version 6 (Fig. 11).

Researchers have identified different types of cellulolytic bacteria from the guts of termite on the basis of 16s rRNA gene analysis.

Table.1 Sequences of primers used for characterization of bacterial isolates

\begin{tabular}{cc}
\hline Primer & Sequence \\
\hline REP F & 5'TCGICTTATCTGGCCTAC3' \\
REP R & 5'TTTTCGTCGTCATCTGGC3' \\
BOXAIR & 5'CTACGGCAAGGCCGACGCTGACG3' \\
ERIC F & 5'AAGTAAGTGACTGGGGTGAGCG3' \\
ERIC R & 5'TGTAAGCTCCTGGGGATTCAC3' \\
\hline
\end{tabular}

Table.2 Thermal profile for amplification of different pairs

\begin{tabular}{|c|c|c|c|c|}
\hline \multicolumn{5}{|c|}{ Primer pair (REP) } \\
\hline Steps & Activity & Temperature $\left({ }^{\circ} \mathbf{C}\right)$ & Time (min) & Repeats \\
\hline 1. & Initial denaturation & $94^{\circ} \mathrm{C}$ & 3 minute & 1 \\
\hline 2. & Final denaturation & $94^{\circ} \mathrm{C}$ & 45 seconds & \\
\hline 3. & Annealing & $38^{\circ} \mathrm{C}$ & 1 minute & 45 cycles \\
\hline 4. & Extension & $72^{\circ} \mathrm{C}$ & 1 minute & \\
\hline 5. & Final extension & $72^{\circ} \mathrm{C}$ & 8 minute & - \\
\hline 6. & storage & $4^{\circ} \mathrm{C}$ & - & - \\
\hline \multicolumn{5}{|c|}{ Primer pair (BOXAIR) } \\
\hline Steps & Activity & Temperature $\left({ }^{\circ} \mathrm{C}\right)$ & Time (min) & Repeats \\
\hline 1. & Initial denaturation & $94^{\circ} \mathrm{C}$ & $3 \mathrm{~min}$. & 1 \\
\hline 2. & Final denaturation & $94^{\circ} \mathrm{C}$ & 45 seconds & \\
\hline 3. & Annealing & $53^{\circ} \mathrm{C}$ & 1 minute & \\
\hline 4. & Extension & $72^{\circ} \mathrm{C}$ & 1 minute & 45 cycles \\
\hline 5. & Final extension & $72^{\circ} \mathrm{C}$ & 8 minute & \\
\hline 6. & Storage & $4^{\circ} \mathrm{C}$ & - & \\
\hline \multicolumn{5}{|c|}{ Primer pair (ERIC) } \\
\hline Steps & Activity & Temperature $\left({ }^{\circ} \mathbf{C}\right)$ & Time (min) & Repeats \\
\hline 1. & Initial denaturation & $94^{\circ} \mathrm{C}$ & $3 \mathrm{~min}$. & 1 \\
\hline 2. & Final denaturation & $94^{\circ} \mathrm{C}$ & 45 seconds & \\
\hline 3. & Annealing & $53^{\circ} \mathrm{C}$ & 1 minute & \\
\hline 4. & Extension & $72^{\circ} \mathrm{C}$ & 1 minute & 45 cycles \\
\hline 5. & Final extension & $72^{\circ} \mathrm{C}$ & 8 minute & \\
\hline 6. & Storage & $4^{\circ} \mathrm{C}$ & - & \\
\hline
\end{tabular}


Table.3 Optimization of parameters for CMCase production

Enzyme activity of potential isolates

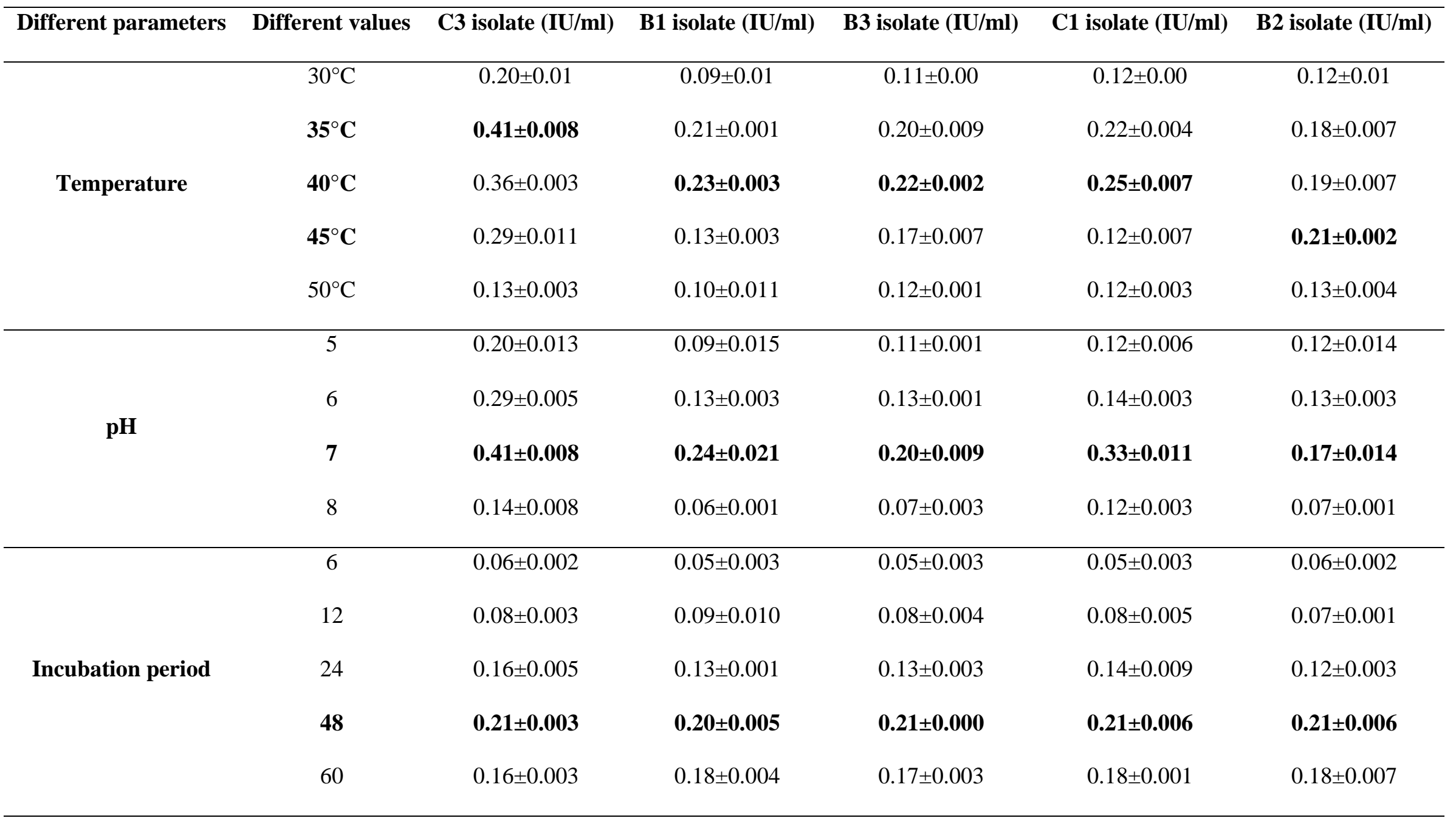

Values after \pm represents standard error of two replicates 
Table.4 Optimization of parameters for avicelase production

\begin{tabular}{ccc}
\hline \hline Different parameters & Different values & Enzyme activity of C3 isolate (IU/ml) \\
\hline \multirow{3}{*}{ Temperature } & $30^{\circ} \mathrm{C}$ & $0.10 \pm 0.001$ \\
& $\mathbf{3 5}^{\circ} \mathbf{C}$ & $\mathbf{0 . 1 4} \pm \mathbf{0 . 0 0 1}$ \\
& $40^{\circ} \mathbf{C}$ & $0.12 \pm 0.004$ \\
& $45^{\circ} \mathbf{C}$ & $0.10 \pm 0.002$ \\
\hline & 5 & $0.13 \pm 0.001$ \\
& 6 & $0.15 \pm 0.002$ \\
& 7 & $\mathbf{0 . 2 1} \pm \mathbf{0 . 0 0 4}$ \\
& 8 & $0.13 \pm 0.004$ \\
\hline \multirow{3}{*}{ Incubation period } & 12 & $0.11 \pm 0.003$ \\
& 24 & $0.14 \pm 0.003$ \\
& $\mathbf{4 8}$ & $\mathbf{0 . 1 7} \pm \mathbf{0 . 0 0 1}$ \\
& 60 & $0.12 \pm 0.001$ \\
\hline
\end{tabular}

Values after \pm represents standard error of two replicates

Table.5 Optimization of parameters for filterpaperase (FPase) production

\begin{tabular}{ccc}
\hline \hline Different parameters & Different values & Enzyme activity of $\mathbf{Z}$ isolate (IU/ml) \\
\hline \multirow{3}{*}{ Temperature } & $30^{\circ} \mathrm{C}$ & $0.056 \pm 0.001$ \\
& $\mathbf{3 5}^{\circ} \mathbf{C}$ & $\mathbf{0 . 1 5} \pm \mathbf{0 . 0 0 4}$ \\
& $40^{\circ} \mathrm{C}$ & $0.12 \pm 0.005$ \\
\hline \multirow{3}{*}{ pH } & 5 & $0.10 \pm 0.003$ \\
& 6 & $0.12 \pm 0.002$ \\
& $\mathbf{7}$ & $0.16 \pm 0.004$ \\
Incubation period & 8 & $0.12 \pm 0.003$ \\
\hline & 12 & $0.15 \pm 0.001$ \\
& 24 & $0.16 \pm 0.001$ \\
& $\mathbf{4 8}$ & $\mathbf{0 . 1 9 \pm 0 . 0 0 5}$ \\
& 60 & $0.17 \pm 0.003$ \\
\hline
\end{tabular}

Table.6 BLASTn results of cellulolytic isolates

\begin{tabular}{clcc}
\hline \hline Bacterial isolate & \multicolumn{1}{c}{ Closest species } & Accession No. & \% identity (Blastn) \\
\hline B1 & Pseudomonas putida & KJ676537.1 & $92 \%$ \\
B2 & Klebsiella pneumoniae & KR269873.1 & $84 \%$ \\
B3 & Serratia species & KF261222.1 & $100 \%$ \\
C1 & Klebsiella pneumoniae & KX010115.1 & $94 \%$ \\
C2 & Enterobacter cloacae & EU073021.1 & $95 \%$ \\
C3 & Klebsiella pneumoniae & KF974478.1 & $96 \%$ \\
M1 & Enterobacter cloacae DD266 & KR822277.1 & $93 \%$ \\
A1 & Pseudomonas plecoglossicida IN88 & KY511070.1 & $97 \%$ \\
Z1 & Pseudomonas plecoglossicida MHF & GQ301534.1 & $95 \%$ \\
L & Pseudomonas sp. V2M2 & FN794214.1 & $81 \%$ \\
R & Pseudomonas putida 1017 & HQ324912.1 & $91 \%$ \\
N & Salmonella entrica ST3 & JQ228520.1 & $92 \%$ \\
Z & Klebsiella variicola ALK036 & KC456522.1 & $95 \%$ \\
B1 Plate & Klebsiella pneumoniae NRC138 & KP313052.1 & $94 \%$ \\
B & Enterobacter aerogens BD1 & KM503142.1 & $86 \%$ \\
C & Enterobacter aerogens BPRIST043 & JF700492.1 & $98 \%$ \\
\hline
\end{tabular}


Fig.1 Effect of Temperature on CMCase activity

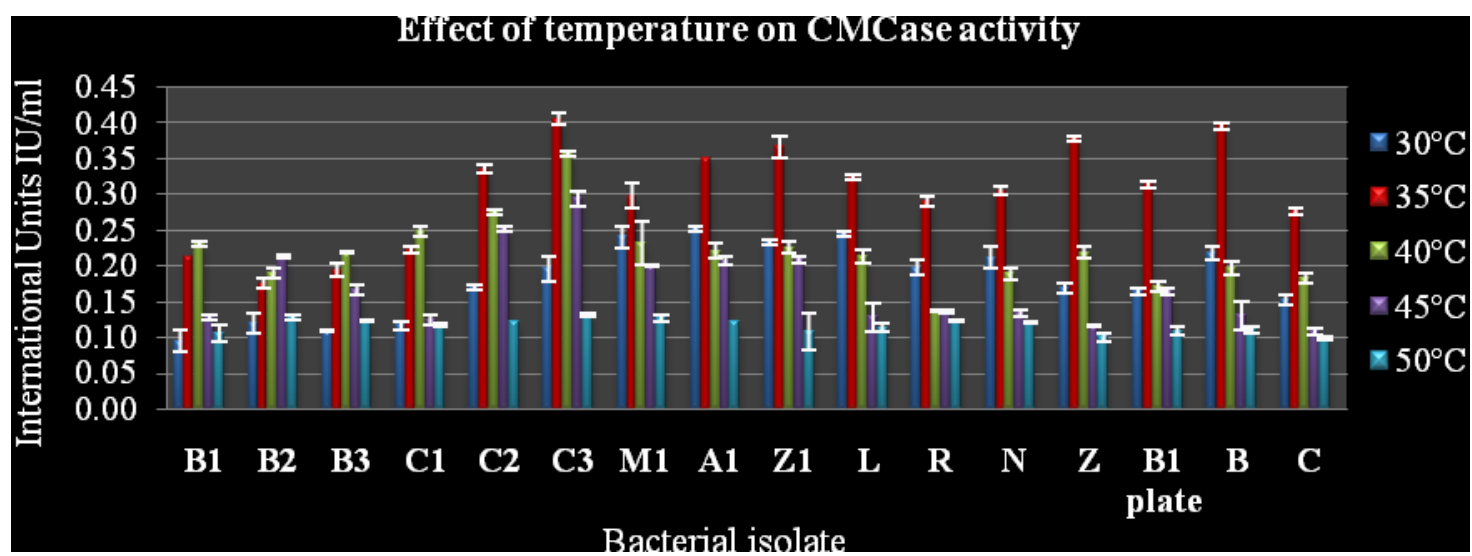

Fig.2 Effect of pH on CMCase activity

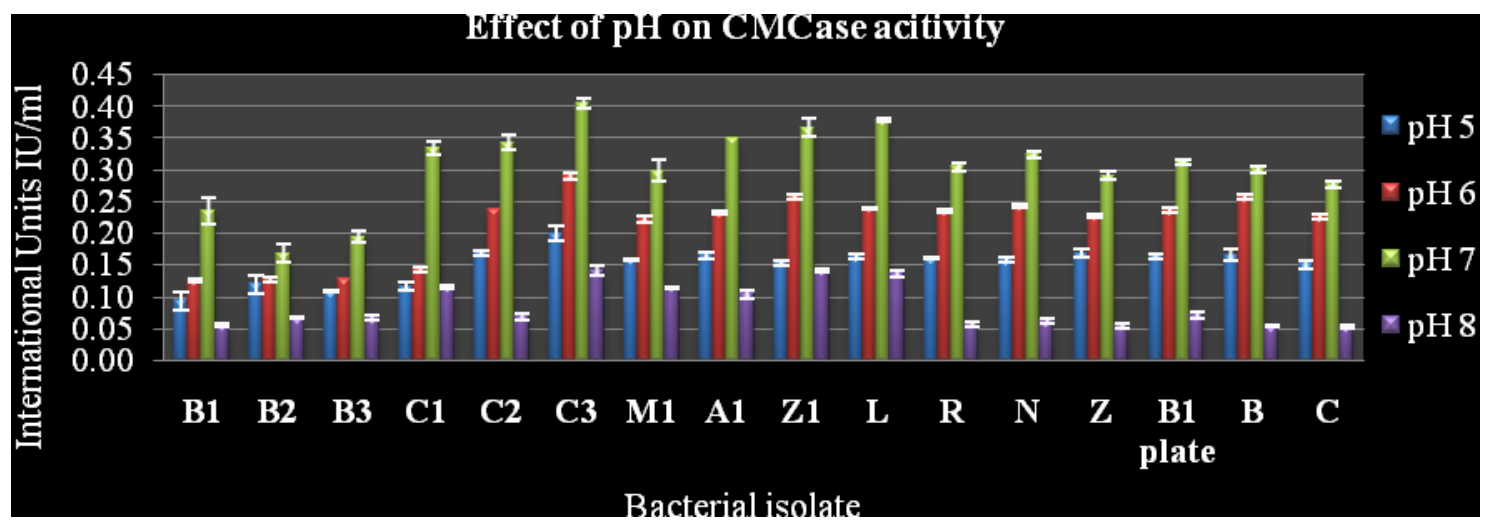

Fig.3 Effect of incubation period on CMCase activity

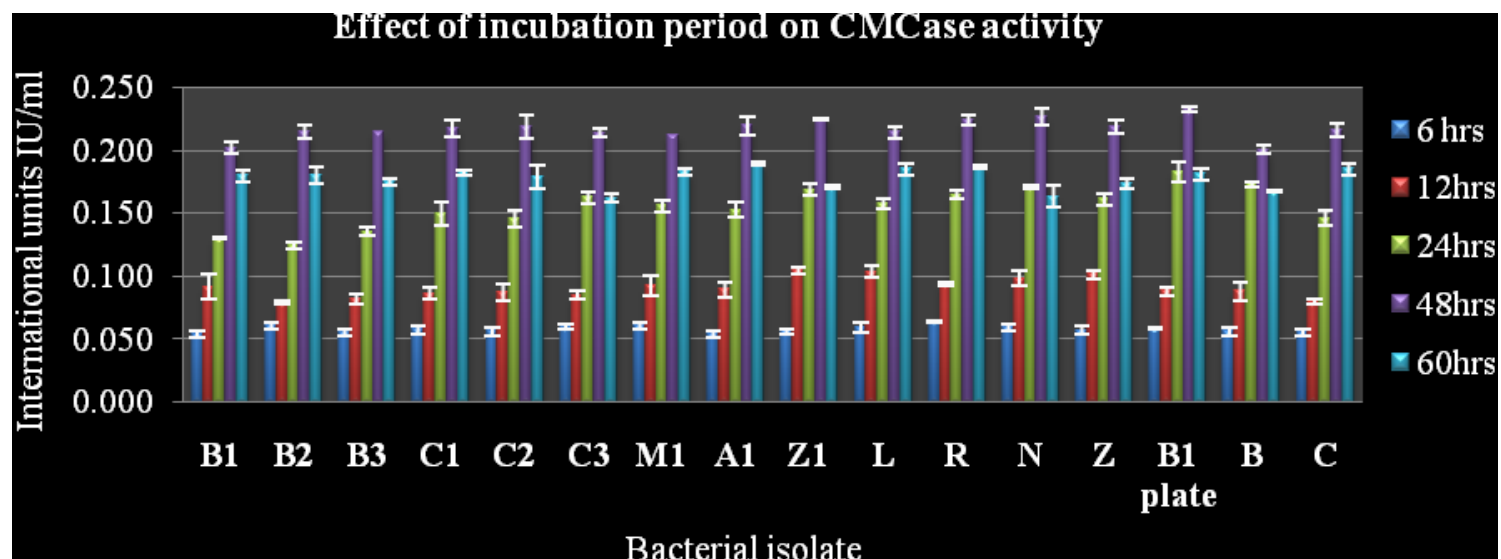




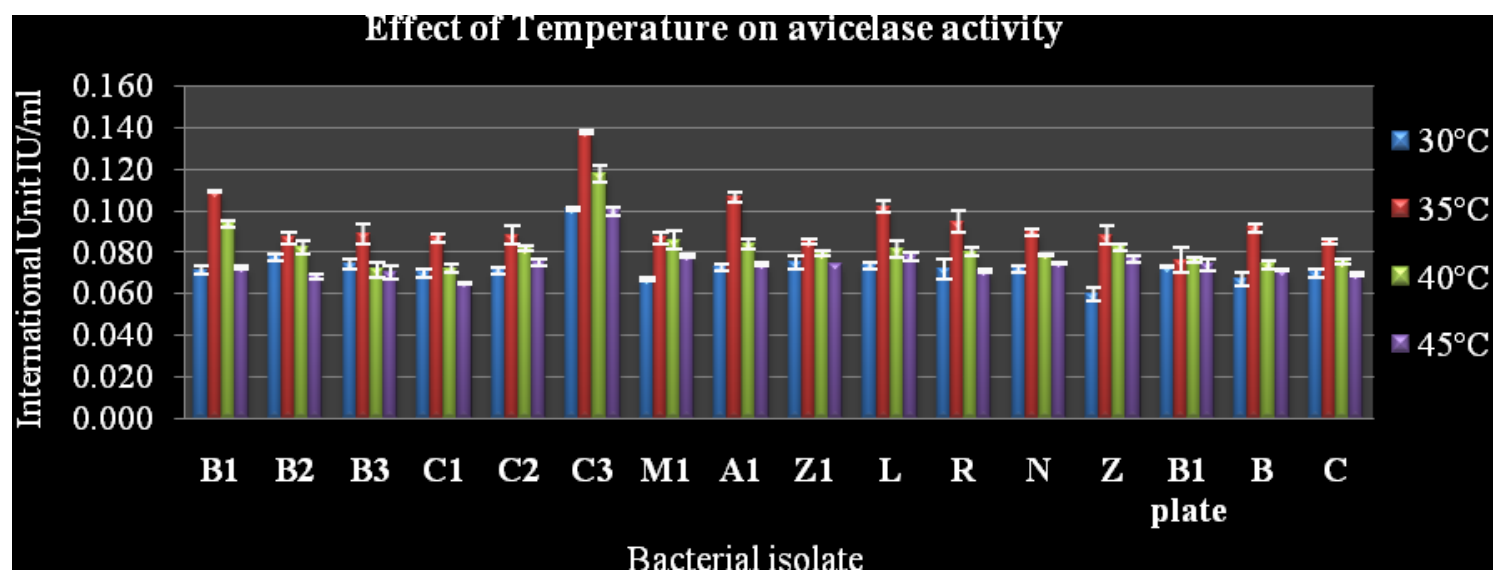

Fig.5 Effect of $\mathrm{pH}$ on avicelase activity

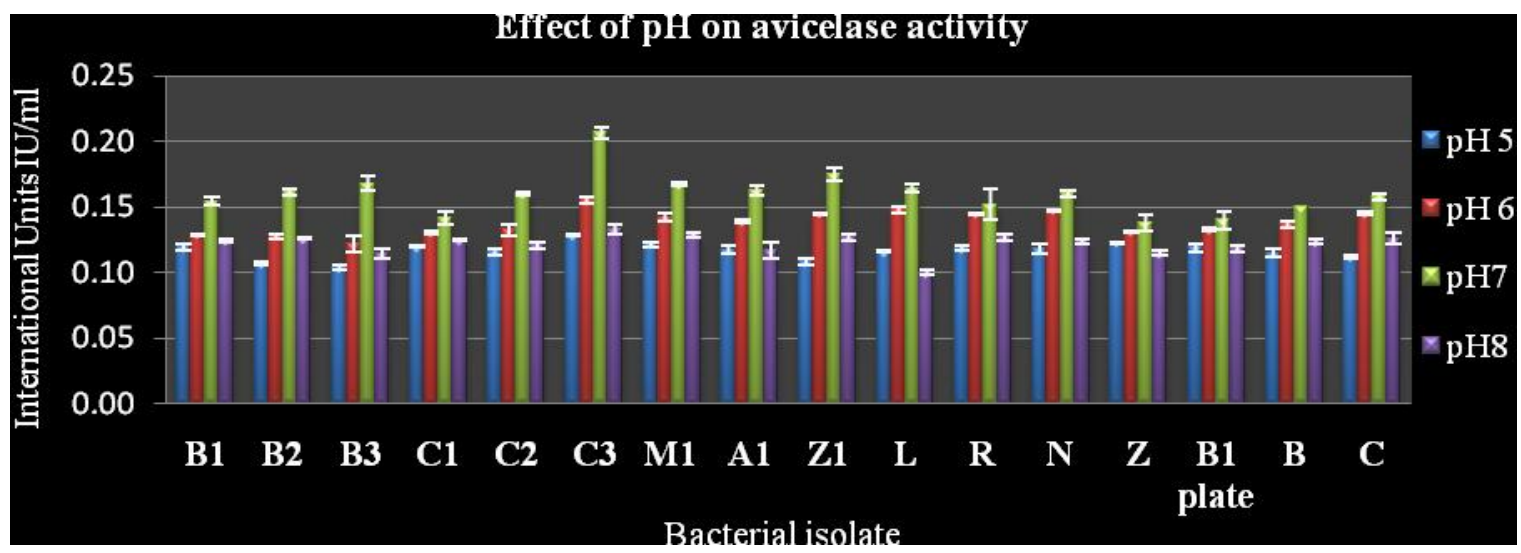

Fig.6 Effect of incubation period on avicelase activity

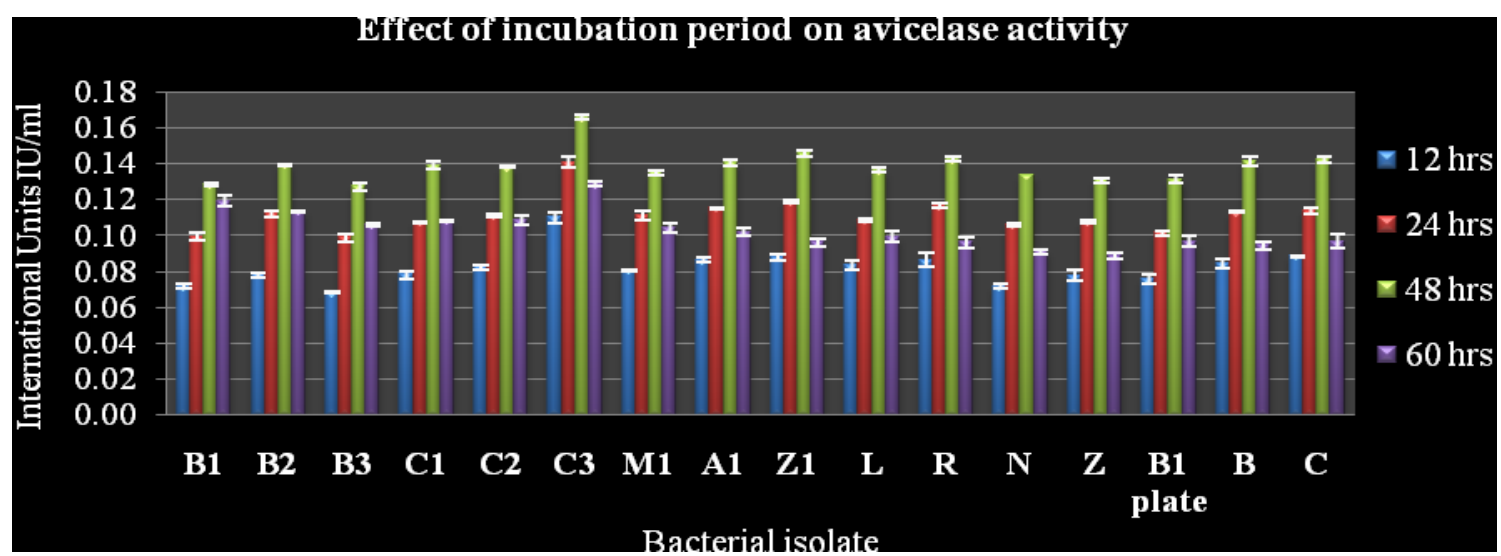


Fig.7 Effect of Temperature on Filterpaperase activity

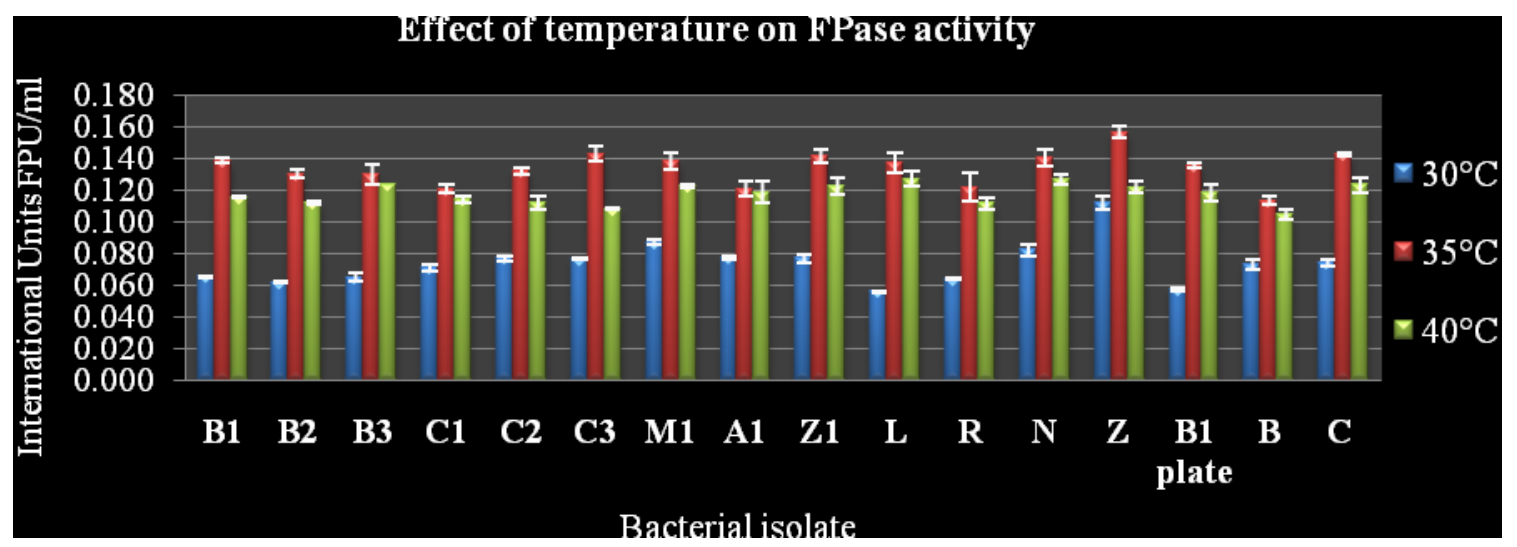

Fig.8 Effect of pH on Filterpaperase activity

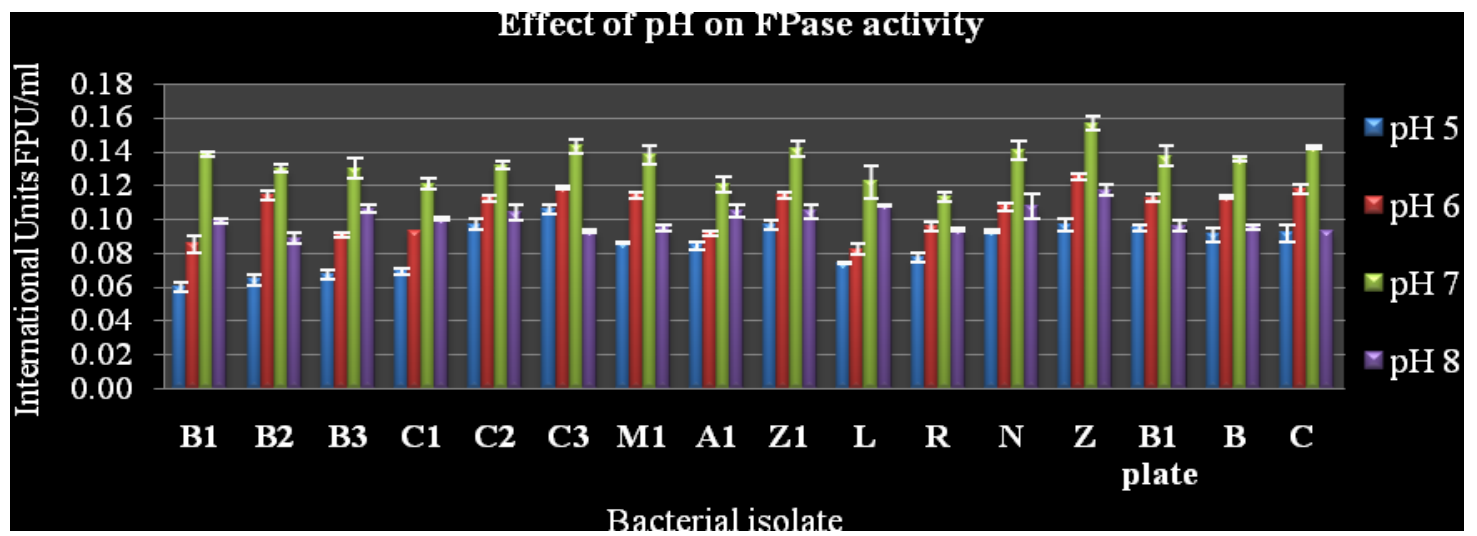

Fig.9 Effect of incubation period on Filterpaperase activity

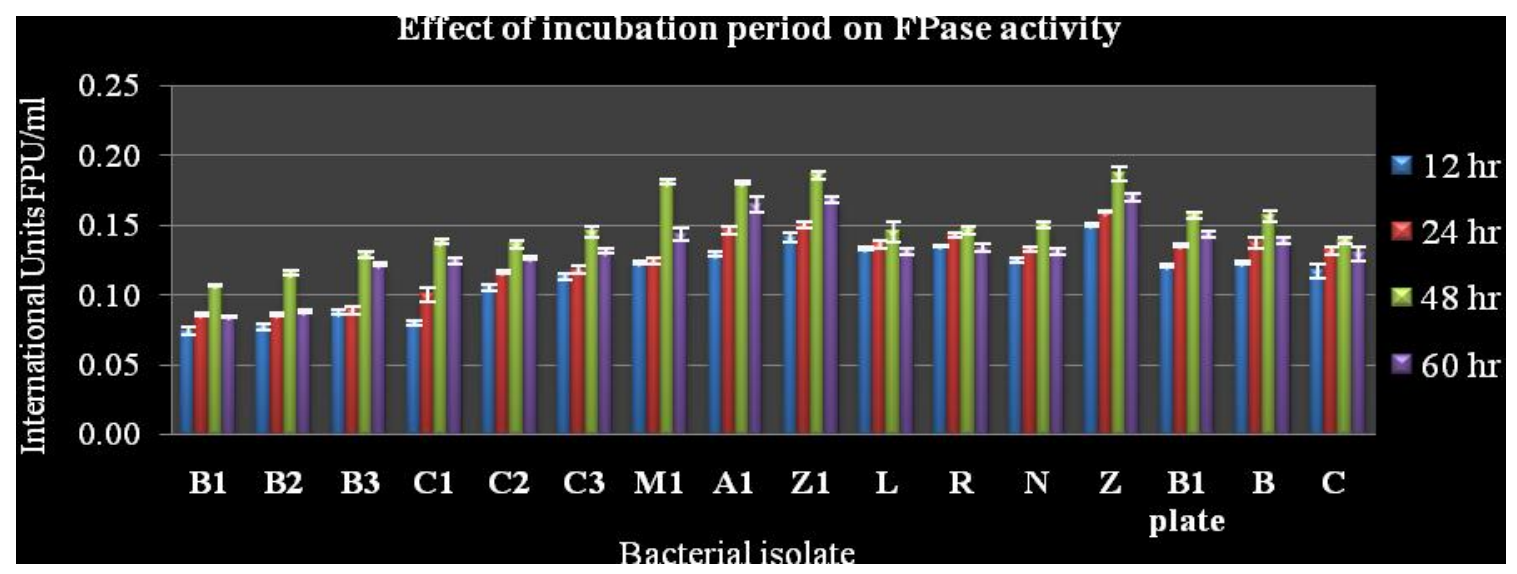


Fig.10 Molecular characterization of potential isolates based on 16s rRNA gene amplification and REP, BOX AND ERIC-PCR genotyping

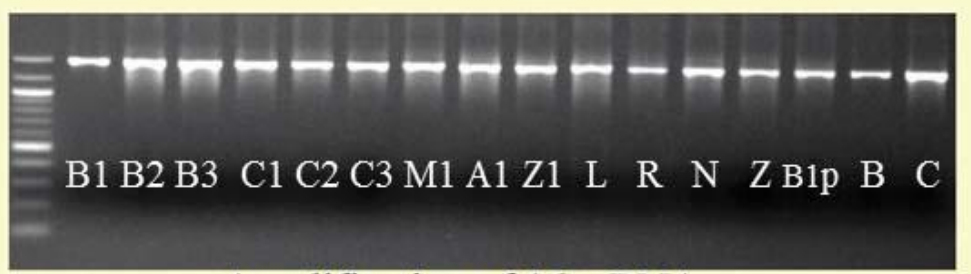

Amplification of $16 \mathrm{~s}$ rRNA

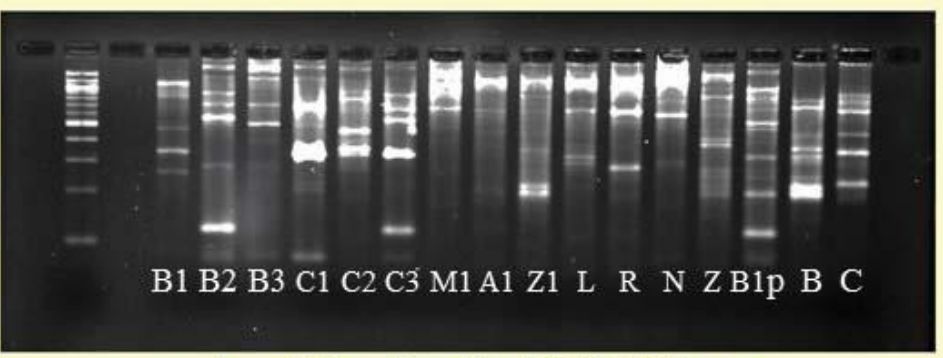

Amplification for ERIC Primer

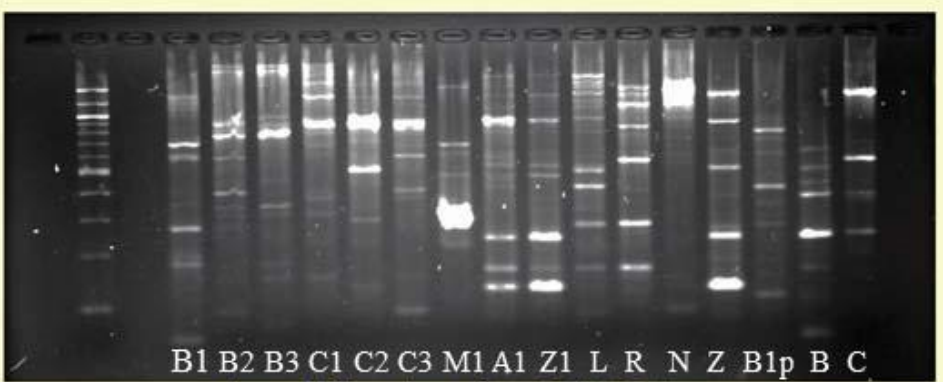

Amplification for REP Primer

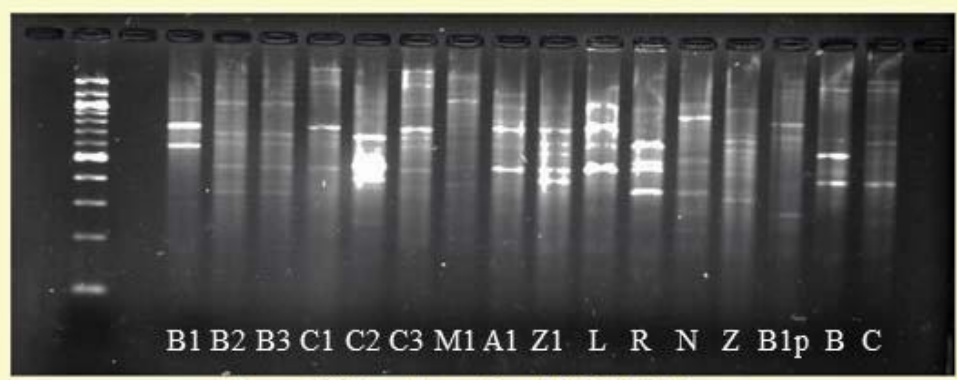

Amplification for $\mathrm{BOX}$ Primer 
Fig.11 Neighbor-joining tree of B2 isolate based on 16s rRNA gene sequences showing phylogenetic position of isolates and related species

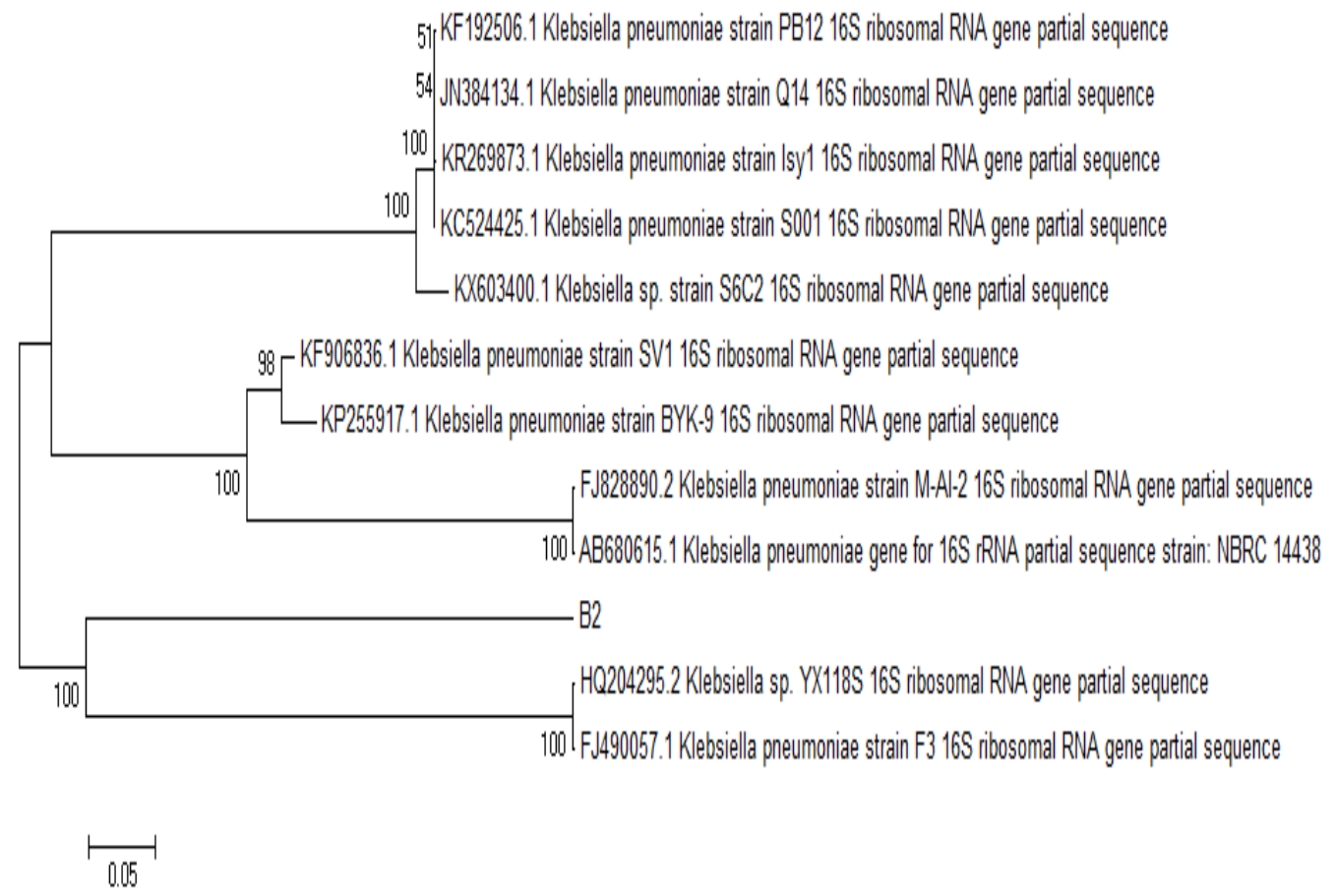

Fig.12 Dendogram of sixteen cellulose degrading isolates generated by binary matrix derived from REP amplicons

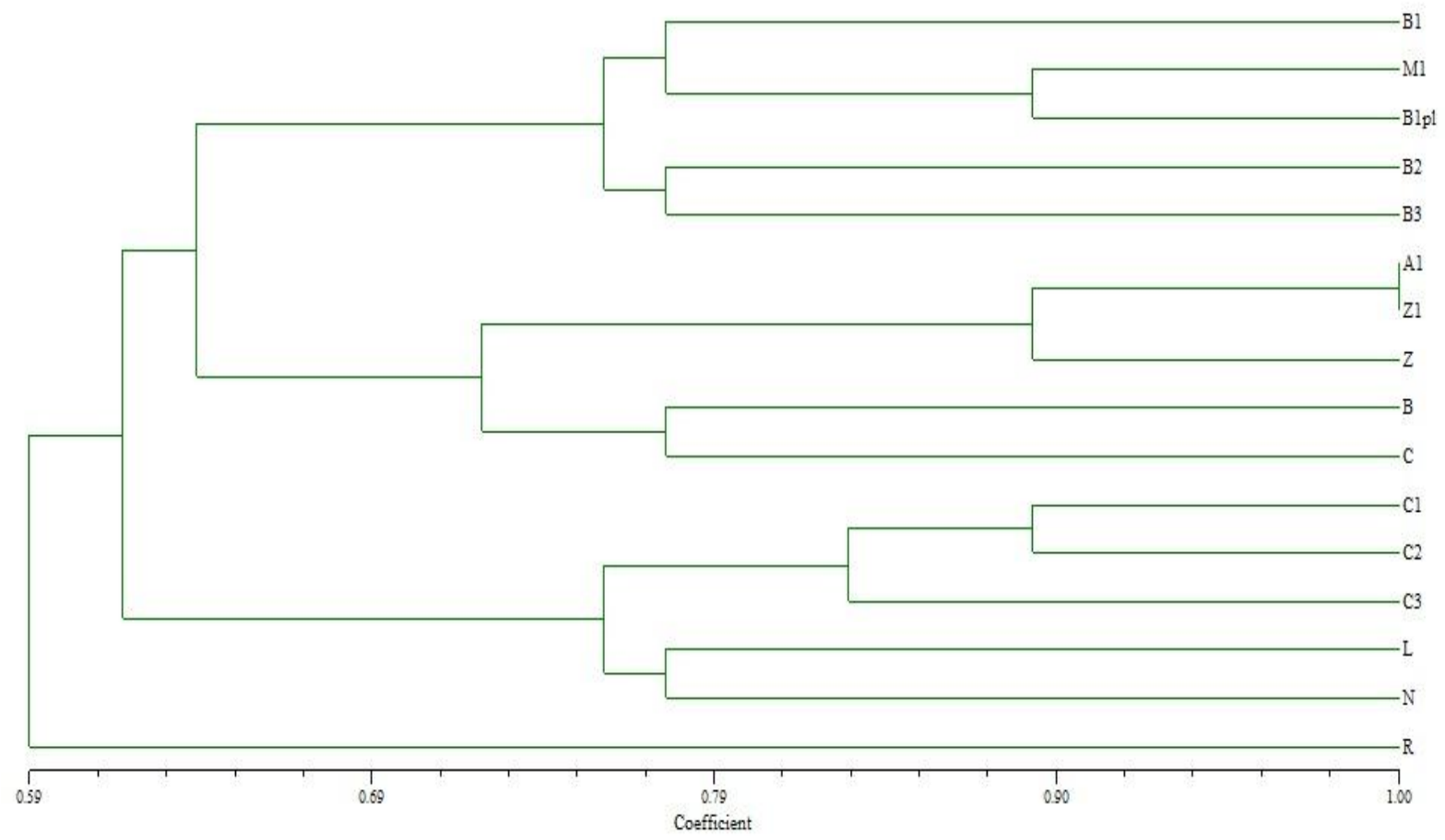


Fig.13 Dendogram of sixteen cellulose degrading isolates generated by binary matrix derived from BOX amplicons

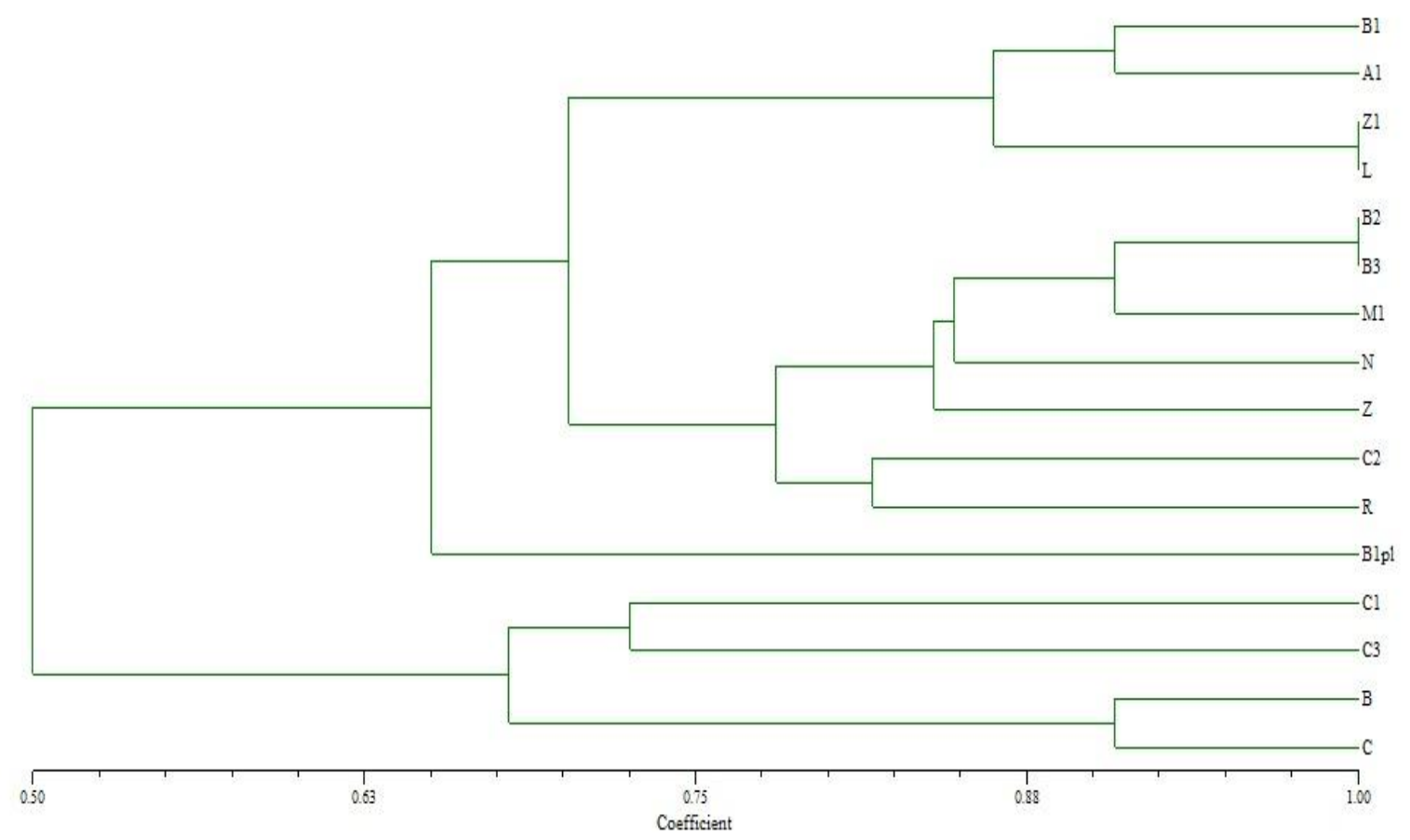

Fig.14 Dendogram of sixteen cellulose degrading isolates generated by binary matrix derived from ERIC amplicons

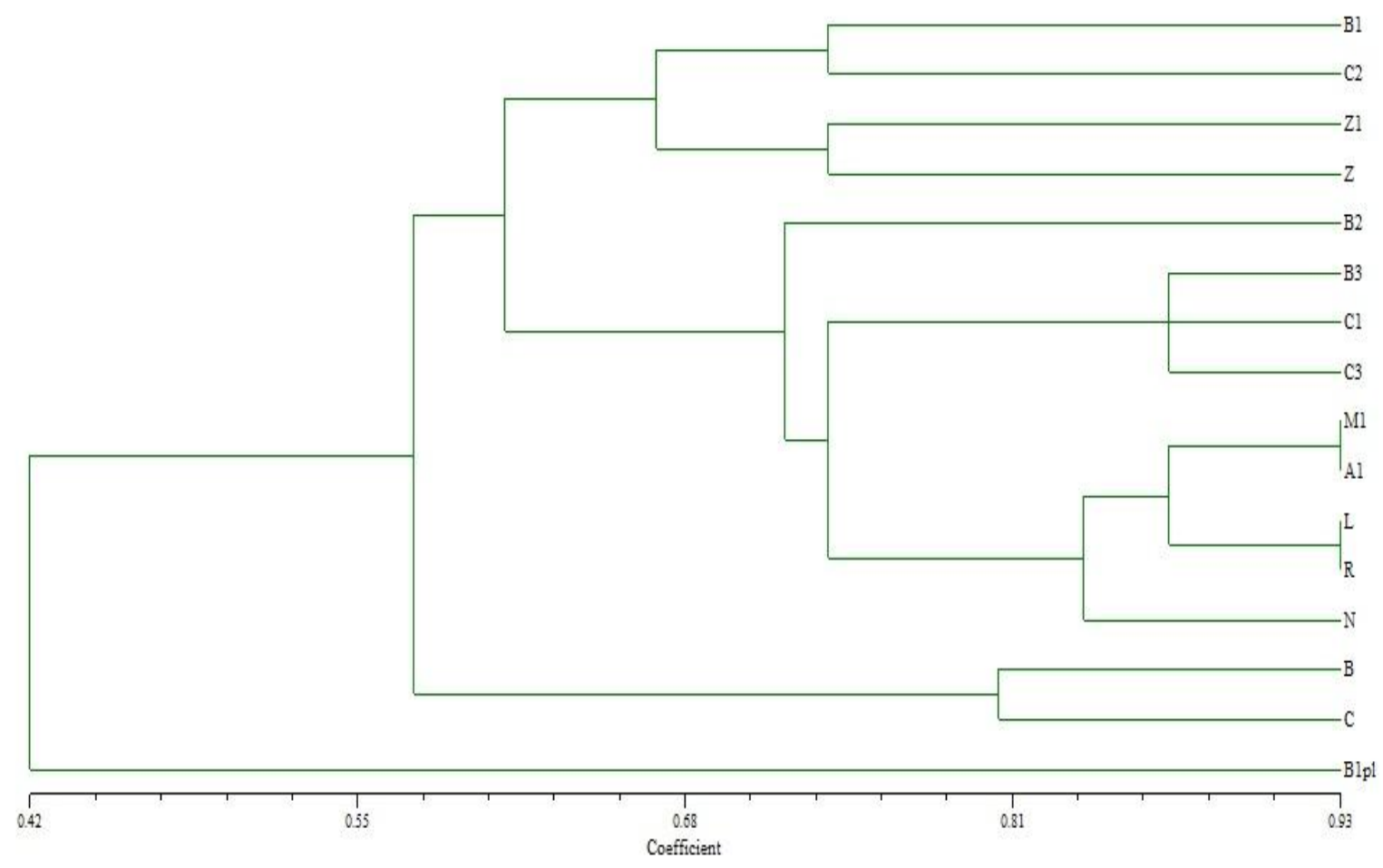


Fig.15 Effect of pH on growth of bacteria

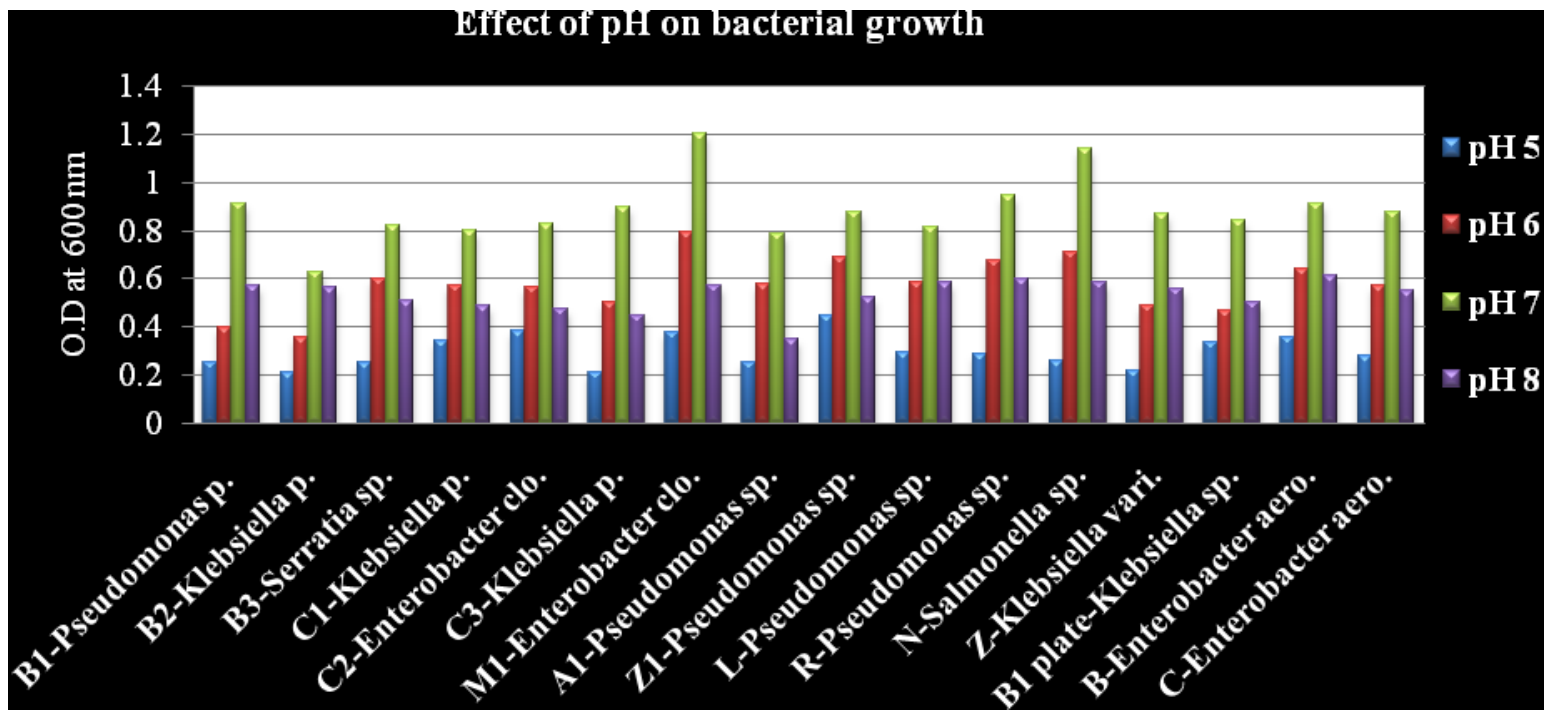

Fig.16 Effect of Temperature on growth of bacteria

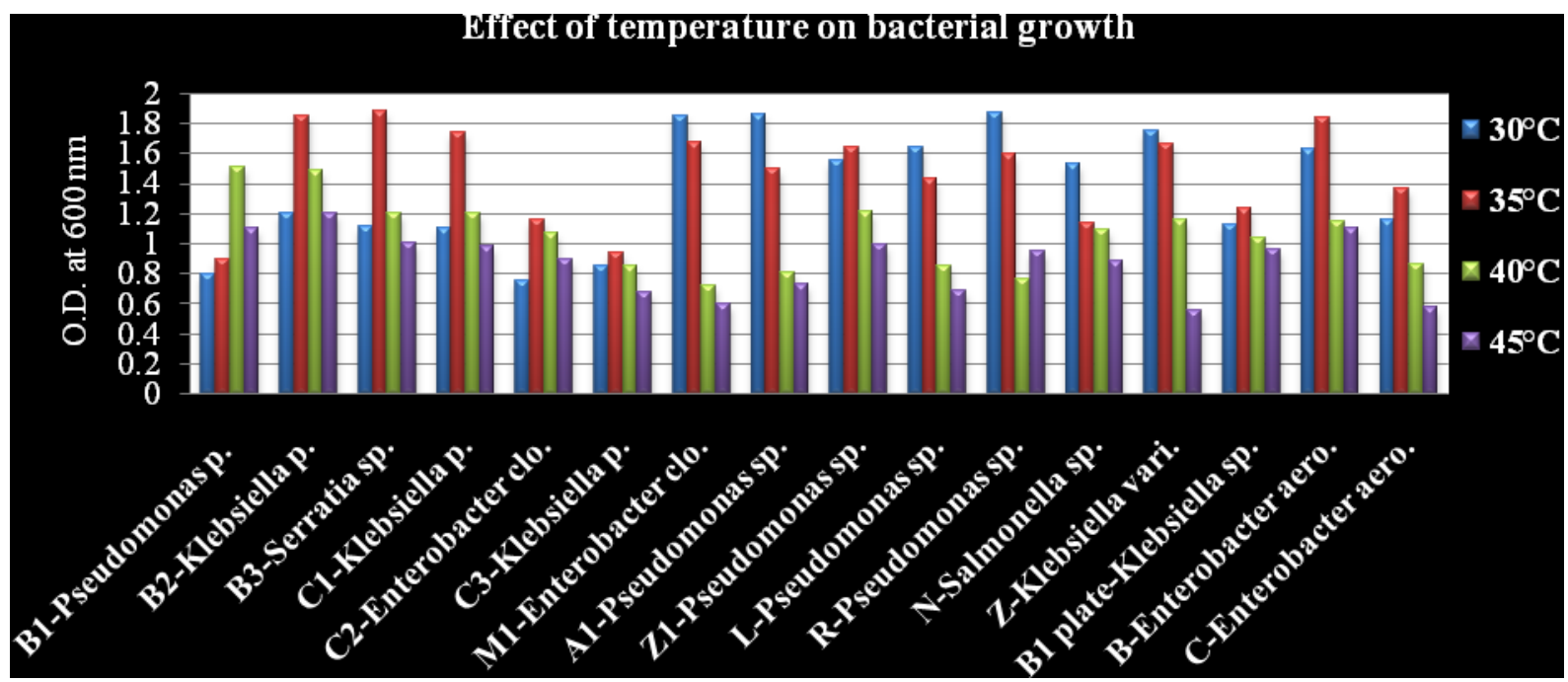

Ramin et al., 2008 isolated bacteria from termite guts and later, bacteria were identified as Bacillus cereusstrain Razmin A, Enterobacteraerogenes strain Razmin B, Enterobacter cloacaestrain Razmin C, Chryseobacteriumkwangyangense strain $\mathrm{Cb}$ and Acinetobacter strain Raminalimon by $16 \mathrm{~s}$
rRNA sequencing. Three cellulose degrading bacteria isolated from local termite guts belonged to the genera Acinetobacter, Pseudomonas and Staphylococcus and four cellulose degrading bacteria belonged to Enterobacteriaceae and Bacillaceae families (Pourramezan et al., 2012).16s rRNA gene of 
cellulolytic bacteria from the termite Odontotermesformosanus was amplified and homology analysis of the sequences showed 90-100\% homology with the Bacillus cereus, Serratiamarcescens, Pseudomonas aeruginosa, Citrobacterfreundii, Enterococcuscasseliflavus, and Salmonella entrica (Kavitha et al., 2014).

\section{REP, BOX AND ERIC-PCR based genotypic analysis}

Rep-PCR fingerprinting (with REP, BOX and ERIC primers) is a highly reproducible and simple method to distinguish closely related microbial strains, to deduce phylogenetic relationships and to study their diversity in different ecosystems (de Bruijn et al., 1992).In the present investigation All REP based fingerprinting primers showed good variability among all isolates as almost polymorphic banding pattern was observed in all 16 isolates. Genetic variability for REP primers ranged from 0.59 to 1.00 . In case of REP clustering, $\mathrm{R}$ isolate did not fall into any group (Fig. 12). Amplification with BOX primer resulted in amplicons of molecular size between 300 to 1300 bp respectively (Fig. 10). Moderate level of variability was observed with BOX based PCR amplification and clustering (Fig. 13). However, a high level of polymorphism was seen in PCR of 16 isolates with ERIC primer. The molecular weights of amplicons after PCR amplification of isolates with ERIC primer ranged between 50 to 1300 bp (Fig. 10). B1 plate isolate did not fall in any group in case of ERIC clustering (Fig. 14). All the isolates exhibited their high degree of genetic variability and distributed in to different clusters with ERIC, BOX and REP primers. This resulted in resolving micro diversity among cellulose degrading isolates and significant levels of genomic heterogeneity between strains within and between sites, respectively. Grouping does not appear to be based on geographic origin. The fingerprints showed wide variations due to high degree of DNA heterogeneity over all the 16 potential isolates. Similarly, work has been reported by other workers such as Charan et al., (2010) who assessed the genetic diversity among Pseudomonas isolates using Rep-PCR.

\section{Effect of pH on growth profile of isolates}

All potential isolates were studied to determine optimum $\mathrm{pH}$ for their growth at various $\mathrm{pH}$ values ranging from $\mathrm{pH} 5$ to 8 . The results clearly indicate that, the optimum $\mathrm{pH}$ for the growth of cellulose degradation bacteria (CDB) was found to be 7.0. However, all the isolates showed moderate growth between $\mathrm{pH} 5$ to 8 (Fig. 15). The isolates, pseudomonas species, Klebsiella species, Serratia species, Salmonella species and Enterobacter species were able to survive both acidic and alkaline environments. Results indicated that increase or decrease in the $\mathrm{pH}$ can affect the growth of cellulolytic bacteria. The effect of $\mathrm{pH}$ on the growth of cellulolytic bacteria was studied by several scientists and optimum $\mathrm{pH}$ for the growth was found between 7 to 7.5 (Hethener et al., 1992, Balamurugan et al., 2011, Maruthamalai et al., 2012 and Bholay et al., 2014). This is in consistence with the results obtained in present investigation.

\section{Effect of Temperature on growth profile of isolates}

All potential isolates were studied to determine optimum temperature for their growth at different temperature ranges $\left(30^{\circ} \mathrm{C}\right.$ to $45^{\circ} \mathrm{C}$ ). The temperature specificity of isolates showed that most of them grew well between $30^{\circ} \mathrm{C}$ to $40^{\circ} \mathrm{C}$. Maximum growth for Pseudomonas putida (B1 isolate) was observed at $40^{\circ} \mathrm{C}$ whereas; other Pseudomonas species (isolates A1, L and R) Salmonella entrica (isolate N) and 
Klebsiellavariicola (isolate Z) showed luxuriant growth at $30^{\circ} \mathrm{C}$. Other isolates such as, Klebsiellapneumoniae (isolates B2, C1, C3 and B1 plate), Serratia species (isolate B3), Enterobacter cloacae (isolates C2 and M1) and Enterobacteraerogens (isolates B and $\mathrm{C}$ ) showed optimum growth at $35^{\circ} \mathrm{C}$. Increasing temperature beyond $40^{\circ} \mathrm{C}$ resulted in growth reduction (Fig. 16). The effect of temperature on the growth of bacteria was studied by several scientists and optimum temperature for the growth was found $30^{\circ} \mathrm{C}$ to $40^{\circ} \mathrm{C}$ (Hethener et al., 1991, Balamurugan et al., 2011, Maruthamalai et al., 2012 and Bholay et al., 2014). This is in consistence with the results obtained in present investigation.

The present work provides information about different parameters for optimum cellulase production, growth profiles, molecular identification, and molecular diversity of sixteen cellulolytic isolates. The potential isolates used in this study were previously isolated from termite guts and their cellulolytic efficiency has already been determined (Shinde et al., 2017). To investigate optimum parameters for cellulase production by these isolates, three substrates namely CMC, avicel and filter paper were used. It was found that, CMCase activity was observed optimum at three different temperatures $\left(35^{\circ} \mathrm{C}, 40^{\circ} \mathrm{C}\right.$ and $\left.45^{\circ} \mathrm{C}\right)$ at $\mathrm{pH} 7$ and after $48 \mathrm{hrs}$ of incubation period whereas, avicelase activity was observed maximum at $35^{\circ} \mathrm{C}, \mathrm{pH} 7$ and after $48 \mathrm{hrs}$ of incubation. Similarly, filterpaperase activity was optimum at $35^{\circ} \mathrm{C}, \mathrm{pH} 7$ and after $48 \mathrm{hrs}$ of incubation. C3 isolate was found highest cellulase producer which was later identified as Klebsiellapneumoniae and $\mathrm{Z}$ isolate (Klebsiellavariicola) showed maximum filterpaperase (FPase) activity. Later, these isolates were subjected to molecular identification by sequencing 16s rRNA gene. After BLAST results, isolates were identified as Pseudomonas, Klebsiella, Salmonella, Serratia and Enterobacter species. Molecular characterization by using ERIC, BOX and REP primers showed variability among these isolates. The temperature and $\mathrm{pH}$ specificity of isolates showed that most of them grew well between $30^{\circ} \mathrm{C}$ to $40^{\circ} \mathrm{C}$ at $\mathrm{pH} 7$. Further studies are in progress to investigate cellulase activity on pretreated rice straw and degradation of lignocellulosic biomass (rice straw) using most potential isolate.

\section{References}

Arakawa, G., Watanabe H, Yamasaki H, Maekawa Hand Tokuda, G. 2009. Purification and molecular cloning of xylanases from the wood-feeding termite, CoptotermesformosanusShiraki.

Biosci.Biotechnol.Biochem.73, 710-718

Balamurugan, A., Jayanthi R, Nepolean P, VidhyaPallavi $\mathrm{R}$ andPremkumar, R.2011.Studies on cellulose degrading bacteria in tea garden soils African J. of Plant. Sci. 5(1): 22-27.

Bholay, A. D., Gaur A, Ganeshan M and Shah, R. 2014.Exploration of cellulolytic potential of Termite gut flora for sustainable development. J. of Environ. Sci.Toxicol\& Food Technol.8(2): 71-76.

Bruijn, F. J. 1992. Use of repetitive (repetitive extragenic, palindromic and enterobacterial repetitive intergenic concensus) sequences and the polymerase chain reaction to fingerprint the genomes of Rhizobium meliloti isolates and other soil bacteria. Appl. Environ. Microbiol. 58, 2180-2187.

Charan, R.A., Reddy P. V, Reddy N. P, Reddy S. S and Sivaramakrishnan, S. 2010. Assesment of Genetic diversity in Pseudomonas fluorescens using PCRbased methods. Biremediation 
Biodiversity and Bioavailability. Pp.1116.

Fauzi,N. A., and Makky, E. A. 2013.Avicelase Enzyme from Sawdust: Isolation, Production and Optimization. Int. J. of Biosci.Biochem.and Bioinformatics. 3(5): 501-504.

Fischer, R., Ostafe R. andTwyman, R. M. 2013. Cellulases from insects. Adv.Biochem.Eng.Biotechnol.136, 5164.

Haripriya, R., and Thirumalaivasan, P. 2017.Isolation of cellulolytic bacteria and production of cellulase from coir pith. Int. J. Res. Ins.4(1): 13-23.

Hethener, P., Brauman A. and Garcia, J. 1992.Clostridium termitidis sp. nov., a Cellulolytic Bacterium from the Gut of the Wood-feeding Termite, Nasutitermes lujae. Appl.Microbiol.15, 52-58.

Kavitha, D., Vijayarani K. and Kumanan, K.2014. 16S rRNA typing of cellulolytic bacteria fromthe termite Odontotermes formosanus.Ind. J. Vet. \& Anim. Sci. Res.43(5): 359 - 368.

Khatiwada, P., Ahmed J, Sohag M. H, Islam K. and Azad, A. K. 2016. Isolation, Screening and Characterization of Cellulase Producing Bacterial Isolates from Municipal Solid Wastes and Rice Straw Wastes. J. of Bioprocess.\& Biotech.6(4): 1-5.

Khianngam, S., Pootaeng-on Y, Techakriengkrai T. and Tanasupawat, S. 2014. Screening and identification of cellulase producing bacteria isolated from oil palm meal. J. of Appl. Pharma.Sci.4(4): 90-96.

Li Xi, Yang H, Roy B, Wang D. Y, Wan F, Jiang Li, Park E. Y. and Miao, Y. 2009. The most stirring technology in future: Cellulase enzyme and biomass utilization. Afr. J.Biotechnol.8, 241822.
Maruthamalai, R. P., and Mahalingam, P. U. 2012.Screening and Partial Characterization of Cellulose Degrading Bacteria from Decayed Sawdust. Int. J of Sci. and Res. 3(8): 328-331.

Miller, G. L. 1959. Use of dinitrosalicylic acid reagent for determination of reducing sugar. Anal. Chem. 31, 426428.

Pourramezan, Z., Ghezelbash G. R, Romani B, Ziaei S. and Hedayatkhah, A. 2012. Screening and Identification of Newly Isolated Cellulose Degrading Bacteria from the Gut of Xylophagous TermiteMicrocerotermes diversus (Silvestri). Microbiol.81(6):736-742.

Ramin, M., Alimon A. R and Abdullah N. 2008. Isolation and identification of bacteria from the termiteCoptotermes curvignathus (Holmgren) present in the vicinity of University Putra Malaysia. Res. J. of Microbiol. 3(4): 288-292.

Rani, R. R. 2015.Microbial Avicelase: an Overview. Bull.Env.Pharmacol. Life Sci. 4(4): 03-13.

Salem, A. A. andRehman, A. H. M. 2015.Optimization and characterization of cellulolytic enzymes produced from Gliocladium roseum. J. Agri. Chem.\& Biotech.6(11): 473-488.

Scharf, M. E. and Tartar, A. 2008.Termite digestomes as sources for novel lignocellulases. Biofuels Bioproducts \& Biorefining 2, 540-552.

Shaikh, N. M., Patel A. A, Mehta S. A. and Patel, N. D. 2013. Isolation and Screening of Cellulolytic Bacteria Inhabiting Different Environment and Optimization of Cellulase Production. Uni. J. of Environ. Res. and Technol.3(1): 39-49.

Sharma, D. 2015. Isolation of Cellulolytic Organisms from the Gut Contents of Termites Native to Nepal and Their Utility in Saccharification and Fermentation of Lignocellulosic 
Biomass. J. of Biomass to Biofuel2,2368-5964.

Shinde, V. S., Shinde R. M, Agrawal T. and Kotasthane, A. S. 2017.Extracellular cellulose activity of termite gut bacteria isolated from different geographical locations of Chhattisgarh (C.G.), India. Plant Archives. 17(1): 601-607.

Sohail, M., Ahmad A. and Khan, S. A. 2014.Comparative studies on production of cellulases from three strains of Aspergillus niger. Pak J. Bot.46 (5): 1911-1914.

Swaroopa, R. D., Thirumale $\mathrm{S}$ andNand, K.2004. Production of cellulase by Clostridium papyrosolvens CFR-703. World J. of Microbiol. \& Biotechnol. 20, 629-632.

Tamura, K., Peterson D, Peterson N, Stecher G, Nei M. and Kumar, S. 2011. MEGA5: Molecularevolutionary genetics analysis using maximum likelihood, evolutionary distance, and maximum parsimony methods. Mol. Biol. Evol 10, 2731-9.

Vimal, J., Venu A. and Joseph, J. 2016. Isolation and identification of cellulose degrading bacteria and optimization of the cellulase production. Int. J. Res.Biosci.5 (3): 58-67.

Willis, J. D., Oppert C. andJurat-Fuentes, J. L. 2010.Methods for discovery and characterization of cellulolytic enzymes from insects. Insect Sci.17, 184-98.

Wood, T. M. and Bhat, K. M.1988.Methods for measuring cellulase activities. Methods in Enzymol. 160: 87-112.

Yadav, S. P., Shruthi K, Siva Prasad B. V. and Chandra, S. M. 2017.Isolation and Identification of Aspergillusprotuberus from Mahanandi Forest Sample and Investigation of Its Cellulase Production. Indian J. of Adv. In Chem.Sci. 5(1): 8-15.

\section{How to cite this article:}

Shinde, V.S., T. Agrawal and Kotasthane, A.S. 2017. Molecular Characterization of Cellulolytic Bacteria Derived From Termite Gut and Optimization of Cellulase Production. Int.J.Curr.Microbiol.App.Sci. 6(10): 2474-2492. doi: https://doi.org/10.20546/ijcmas.2017.610.292 